\title{
Effects of type of liquid feed and feeding frequency on calf performance*
}

\author{
B. Niwińska ${ }^{1}$ and J. A. Strzetelski \\ Department of Animal Nutrition, \\ National Research Institute of Animal Production \\ 32-083 Balice, Poland
}

\begin{abstract}
The effects of liquid feed and feeding frequency on concentrate mixture intake, rumen fermentation and rearing performance were investigated in 24 bull calves divided into 2 groups, receiving milk or milk-replacer once or three times a day. VFA concentration was estimated in the rumen fluid at 36 and 90 days of age. The liquid feed did not influence the concentrate intake $(\mathrm{P}>0.05)$. The calves receiving milk were characterized by higher concentration of butyric acid in the rumen fluid $(\mathrm{P} \leq 0.02)$ and higher daily weight gains $(\mathrm{P} \leq 0.02)$ compared with those fed milkreplacer. The increasing feeding frequency during the period from 7 to 36 days of age was reflected in lower daily intake of concentrate mixture $(\mathrm{P}=0.02)$.
\end{abstract}

KEY WORDS: calves, liquid feed, feeding frequency, performance

\section{INTRODUCTION}

The changes in milk-replacer formulas led to the replacement of dried skim milk with plant products, which in nonruminant calves decrease nutrient utilization (Montagne et al., 2003). The negative effect on performance of calves is also exerted by the once daily feeding system (Strzetelski et al., 2001). When the daily diet is divided into more portions calves are characterized by the homeostasis of blood metabolites, which is beneficial for calf's growth (Kaufhold et al., 2000). The effects of liquid feed composition and frequency of feeding on the rearing performance of calves are not really recognized.

The aim of the experiment was to study the effects of type of liquid feed and frequency of feeding on concentrate intake, rumen fermentation and rearing performance of calves.

\footnotetext{
* The study was performed within the framework of the statutory activities of the National Research Institute of Animal Production, Project No. 23217.1

${ }^{1}$ Corresponding author: e-mail: niwb@izoo.krakow.pl
} 


\section{MATERIAL AND METHODS}

The experiment was carried out with 24 Black-and-White Lowland bull calves, divided at 7 days of age into 2 groups (12 animals per group). In Group M calves received milk and in Group MR isonitrogenous solution of milk replacer once (subgroups-1) or three times a day (subgroups-2). Milk replacer protein was composed of (\%): soya protein concentrate, 60, and whey, 40. From each subgroup three calves aged $36( \pm 2.2)$ days and three calves aged $90( \pm 4.3)$ days were slaughtered and rumen contents were removed for volatile fatty acids (VFA) analysis. The calves were fed according to IZ-INRA (2001) recommendations and the individual intake of feed was monitored. All of the calves were given to appetite concentrate consisting of (\%): rolled barley, 50; wheat bran, 6 ; soyabean oilmeal, 17; rolled wheat, 25; and mineral mixture 2.

Proximate analysis of feeds was carried out according to AOAC (1990), the nutritive value of feeds and concentrate mixture was formulated according to the INRA (1989) system using Winwar ver. 1.6 (2000) and Winmix ver. 1.7 (2000) software packages. VFA concentrations were determined as methyl esters using VARIAN 3400 equipment with CPWax-58 column. The results were analysed statistically using the two-way (type of liquid feed and feeding frequency) analysis of variance procedure of STATISTICA (ver. 5.1).

\section{RESULTS}

Nutrient content and feed value are given in Table 1.

Table 1. Nutrient content and nutritive value of feed

\begin{tabular}{lcccccccccc}
\hline & Dry & \multicolumn{7}{c}{ In 1 kg of DM, g } \\
\cline { 3 - 10 } Item & $\begin{array}{c}\text { matter } \\
\text { g/kg }\end{array}$ & $\begin{array}{c}\text { crude } \\
\text { protein }\end{array}$ & $\begin{array}{c}\text { ether } \\
\text { extract }\end{array}$ & $\begin{array}{c}\text { crude } \\
\text { fibre }\end{array}$ & ash & UFL & PDIN & $\begin{array}{c}\text { digested } \\
\text { protein }^{1}\end{array}$ & \multirow{2}{*}{ PDIE } \\
\hline Concentrate mixture & 875.3 & 189.1 & 15.7 & 47.5 & 61.4 & 1.17 & 130 & & 131 \\
Cow's milk & 125.6 & 266.7 & 319.3 & - & 59.7 & 1.90 & - & 253.3 & - \\
Milk replacer & 947.0 & 215.8 & 154.4 & 10.1 & 77.1 & 1.53 & - & 204.9 & - \\
\hline
\end{tabular}

${ }^{1}$ digested crude protein was estimated according to INRA (1989)

The daily intakes of the concentrate mixture were similar in groups $\mathrm{M}$ and MR ( $P>0.05$; Table 2). The higher concentration of butyric acid $(\mathrm{P} \leq 0.02)$ and a tendency to the lower concentration of propionic acid $(\mathrm{P}=0.06)$ in the rumen fluid of calves fed milk in comparison with those receiving milk replacer were found. From 7 until 36 days of age higher daily intake of concentrate was estimated in the calves receiving liquid feed once a day compared with those fed more frequently $(\mathrm{P}=0.02)$. 
Table 2. The daily intake of concentrate mixture (DI) and VFA concentration in the rumen fluid

\begin{tabular}{|c|c|c|c|c|c|c|c|c|}
\hline \multirow{2}{*}{ Item } & \multicolumn{2}{|c|}{ Liquid feed } & \multirow{2}{*}{$\mathrm{P}^{1}$} & \multicolumn{2}{|c|}{ Frequency } & \multirow{2}{*}{$P$} & \multirow{2}{*}{ Means } & \multirow{2}{*}{ SEM } \\
\hline & M & MR & & 1 & 2 & & & \\
\hline \multicolumn{9}{|l|}{ From 7 until 36 days of age } \\
\hline \multirow{2}{*}{ DI of: liquid feed, $\mathrm{kg}$} & 6.47 & 5.69 & 0.01 & 5.91 & 6.24 & 0.02 & 6.1 & 0.3 \\
\hline & 0.07 & 0.08 & 0.7 & 0.11 & 0.06 & 0.02 & 0.08 & 0.02 \\
\hline \multirow{3}{*}{$\begin{array}{l}\text { sum of VFA, } \mathrm{mmol} / \mathrm{L} \\
\begin{aligned} \% \mathrm{~m}^{2} & \text { propionic acid } \\
& \text { butyric acid }\end{aligned}\end{array}$} & 133.7 & 177.1 & 0.2 & 120.0 & 190.8 & 0.07 & 155.4 & 22.9 \\
\hline & 26.58 & 28.46 & 0.06 & 29.96 & 25.07 & 0.1 & 27.52 & 1.92 \\
\hline & 12.45 & 6.20 & 0.01 & 8.58 & 10.07 & 0.3 & 9.33 & 1.08 \\
\hline \multicolumn{9}{|l|}{ From 7 until 90 days of age } \\
\hline \multirow{2}{*}{$\begin{array}{l}\text { DI of: concentrate mixture, } \mathrm{kg} \\
\text { sum of VFA, mmol/L }\end{array}$} & 1.11 & 0.97 & 0.06 & 1.02 & 1.06 & 0.6 & 1.04 & 0.07 \\
\hline & 129.1 & 177.9 & 0.3 & 160.9 & 146.1 & 0.7 & 153.5 & 20.5 \\
\hline \multirow{2}{*}{$\begin{array}{cl}\% \mathrm{~m}^{2} & \text { propionic acid } \\
\text { butyric acid }\end{array}$} & 32.64 & 34.62 & 0.07 & 33.25 & 34.01 & 0.8 & 33.63 & 1.25 \\
\hline & 6.72 & 5.62 & 0.02 & 6.20 & 6.15 & 0.9 & 6.17 & 0.28 \\
\hline
\end{tabular}

${ }^{1}$ the differences were accepted to be non-significant at $\mathrm{P}>0.05$

${ }^{2} \mathrm{mmol} / 100 \mathrm{mmol}$ of sum VFA

Higher daily weight gains (DWG) and efficiency of PDI and UFL utilization per 1 $\mathrm{kg}$ of weight gain were noted for calves in Group M compared to calves in Group MR $(\mathrm{P} \leq 0.04$, Table 3$)$. From 7 to 36 days of age higher DWG of calves receiving liquid feed three times a day compared with those fed less frequently were noted $(\mathrm{P}=0.04)$.

Table 3. Daily weight gains (DWG) and feed utilization per $1 \mathrm{~kg}$ of weight gain (WG)

\begin{tabular}{|c|c|c|c|c|c|c|c|c|}
\hline \multirow{2}{*}{ Item } & \multicolumn{2}{|c|}{ Liquid feed } & \multirow{2}{*}{$P$} & \multicolumn{2}{|c|}{ Frequency } & \multirow{2}{*}{$\mathrm{P}$} & \multirow{2}{*}{ Means } & \multirow{2}{*}{ SEM } \\
\hline & $\mathrm{M}$ & MR & & 1 & 2 & & & \\
\hline \multicolumn{9}{|l|}{ From 7 until 36 days of age } \\
\hline DWG, g & 716 & 381 & 0.001 & 484 & 615 & 0.04 & 548 & 62 \\
\hline per $1 \mathrm{~kg}$ of WG: liquid feed, $\mathrm{kg}$ & 9.04 & 14.9 & 0.003 & 12.2 & 10.2 & 0.08 & 11.7 & 1.6 \\
\hline concentrate mixture, $\mathrm{kg}$ & 0.10 & 0.21 & 0.004 & 0.23 & 0.10 & 0.06 & 0.15 & 0.03 \\
\hline PDI, g & 296 & 502 & 0.004 & 424 & 372 & 0.09 & 398 & 184 \\
\hline UFL & 2.20 & 3.76 & 0.004 & 3.15 & 2.76 & 0.08 & 2.97 & 0.43 \\
\hline \multicolumn{9}{|l|}{ From 7 until 90 days of age } \\
\hline DWG, g & 939 & 731 & 0.02 & 835 & 834 & 0.9 & 835 & 41 \\
\hline per $1 \mathrm{~kg}$ of WG: concentrate, $\mathrm{kg}$ & 1.26 & 1.81 & 0.06 & 1.47 & 1.52 & 0.6 & 1.50 & 0.06 \\
\hline PDI, g & 276 & 300 & 0.02 & 287 & 288 & 0.9 & 288 & 6.0 \\
\hline UFL & 2.28 & 2.47 & 0.02 & 2.37 & 2.38 & 0.9 & 2.38 & 0.05 \\
\hline
\end{tabular}

\section{DISCUSSION}

The results obtained demonstrate that the calves receiving milk were characterized by significantly higher content of butyric acid in the sum of VFA in 
the rumen fluid ( $12.5 \%$ at 36 days of age) compared with those fed milk-replacer $(6.2 \%)$, although daily concentrate mixture intake was similar (mean $0.08 \mathrm{~kg}$ ). The reasons for these differences are unclear. Calf's rumen development is accompanied by an increase in oxidation of butyrate, the main source of energy for ruminal epithelial tissue. At weaning production of $\beta$-hydroxybutyrate from butyrate increases sixfold (Baldwin and Jesse, 1992). It seems that the considerably higher weight gains of milk-fed calves noted in our study could have proceeded from the higher butyric acid production. There are many reasons why the calves fed milk grew better and more efficiently utilized nutrients than those fed milk replacer. The considerable level of soyabean protein included in the milk replacer (nearly 60\%) decreased the protein utilization. Montagne et al. (2003) found that both the intestinal breakdown of protein and the absorption of oligopeptides from plant protein were significantly lower compared with those derived from milk. Additionally, milk is a rich source of components with beneficial functionality in young animal nutrition (bioactive peptides, hormones, lactoferrin); milk replacers are not supplemented with substances like those (Zabielski, 2001).

The lower daily weight gains of calves fed once a day during the period from 7 to 36 days of age indicated the lack of beneficial influences of the higher concentrate consumption. Probably, the increase in the concentrate intake was forced by the long interval between the feeding periods, and further the maturity processes of the digestive tract were limited by the age of animals, resulting in poor utilization of concentrate (Baldwin and Jesse, 1992; Strzetelski et al., 2001).

In conclusion, the type of liquid feed did not influence the concentrate intake but induced differences in rumen fermentation. The increasing feeding frequency was reflected in the lower daily intake of concentrate mixture.

\section{REFERENCES}

AOAC, 1990. Association of Analytical Chemists, Official Methods of Analysis. $15^{\text {th }}$ Edition. Arlington, VA

Baldwin R.L., Jesse B.W., 1992. Developmental changes in glucose and butyrate metabolism by isolated sheep rumen epithelial cells. J. Nutr. 122, 1149-1153

INRA, 1989. Alimentation des Bovins, Ovins, Caprins. R. Jarrige (Editor). Paris

IZ-INRA, 2001. Research Institute of Animal Production. Standards of Cattle, Sheep and Goats Feeding (in Polish). Instytut Zootechniki, Balice (Poland)

Kaufhold J.N., Hammon H.M., Bruckmaler R.M., Breier B.H., Blum J.W., 2000. Postprandial metabolism and endocrine status in veal calves fed at different frequencies. J. Dairy Sci. 83, 2480-2490

Montagne L., Crévieu-Gabriel I., Toullec R., Lallés J.P., 2003. Influence of dietary protein level and source on the course of protein digestion along the small intestine of veal calf. J. Dairy Sci. 86, 934-943

Strzetelski J.A., Niwińska B., Kowalczyk J., Jurkiewicz A., 2001. Effect of replacer feeding frequency and level on concentrate intake and rearing performance of calves. J. Anim. Feed Sci. 10, 413-420

Zabielski R., 2001. Bioactive peptides in young animal nutrition. J. Anim. Feed Sci. 10, Suppl. 1, $169-180$ 